\title{
Molecular and Biochemical Studies of Gamma Irradiated Rates Treated by Mesenchymal Stem Cells and Natural Antioxidant
}

\author{
Ashraf Z. Mahmoud ( $\nabla$ ashrafzakaria@mans.edu.eg ) \\ Mansoura University \\ M. R. El.Sawi \\ Mansoura University \\ M. N. Habza \\ Mansoura University
}

\section{Article}

Keywords: Irradiation, silymarin, mesenchymal stem cells transplantation, oxidative stress.

Posted Date: April 20th, 2022

DOl: https://doi.org/10.21203/rs.3.rs-1318895/v2

License: (c) (i) This work is licensed under a Creative Commons Attribution 4.0 International License. Read Full License 


\section{Abstract}

Purpose: Therapeutic effect of mesenchymal stem cells transplantation (MSCs) and natural antioxidant such as silymarin have been postulated as hepato-protectors against ionizing radiation induced harm. The present study was undertaken to evaluate the protective effect of (MSCs) and silymarin to ameliorate damage caused by gamma radiation.

Materials and methods: Three days before irradiation, rats were given silymarin at a dose of $70 \mathrm{mg} / \mathrm{kg}$ dissolved in distilled water and continued for another 21 days. One day after gamma irradiation at a dose level of $4 \mathrm{~Gy}$, male rats were transplanted by bone marrow mesenchymal stem cells (BMMSCs) through intravenous injection.

Results: One and three weeks after irradiation, irradiated animals receiving transplanted mesenchymal stem cells (TMSCs) and silymarin seperatly or with each other exhibited a pronounced elevation in liver antioxidant such as Glutathione (GSH) superoxide dismutase (SOD), glutathione - S- transferase (GST), total antioxidant capacity (TAC), catalase (CAT) and glucose-6-phosphate dehydrogenase (G-6-PDase) activity accompanied with significantdecline in lipid peroxidation and hydrogen peroxide levels in comparing with irradiated rats. Moreover, RAPD-PCR with primers OP-B10 and OP-B14 exhibited strong and different banding patterns in all treated rats compared to untreated control rats after 1 and 3 weeks of treatment.

Conclusion: Treatment with MSCs and silymarin possess a radio protective capacity against ionizing-radiation induced oxidative stress and organ injury.

\section{Introduction}

Stem cells are a type of progenitor cell that can differentiate into a variety of different types of cells in the body. When stem cells divide, each new cell has the option of remaining a stem cell or transforming into a different type of cell with a different purpose (Pittengeret al., 2019). All stem cells unrelatedly to their origin have two important features: first, stem cells are unspecified cells that can be differentiated into specified cells.Second; stem cells are being abled to split and regenerate for long times (Zakrzewskiet al., 2019).

Most therapeutic applications of stem cells in human diseases are repairing injured heart by reducing inflammation, collagen deposition and remolding (Guo et al., 2020), Leukemia (Dessieet al., 2020), Neurodegenerative diseases (Yaoet al., 2020), Parkinson's disease (Liu and Cheun g, 2020), Alzheimer's disease (Si and Wang, 2021), repair injured liver (Leeet al., 2021), and Type 1 diabetes (Chenet al., 2020; Abdullah and Alshammary, 2020). Moreover, stem cells are generally used in experimental models in curative uses for the curing of musculoskeletal damages in mammalian animals (Pradkaet al.,2021) and promoting fertility potential in sterile male rats (Qa maret al.,2021 and Zhankinaet al., 2021).

Recently, interest for using natural occurring antioxidant in nutrition or medical materials increased instead of artificial antioxidants, which are being limited because of their lateral effects such as carcinogenicity (Lourençoet al., 2019). Silymarin is a mix. of flavonoid components that is isolated from the Silybummarianum (L.) Gaertn (milk thistle) plant and is well known as a natural antioxidant. It belongs to the Asteraceae family of Angiosperms, which also includes daisies, asters, and sunflowers (Azozet al., 2019). Phenols and flavonoids are natural antioxidants exhibited protective actions in various examples of toxin-produced oxidative stress (Kaurinovic and Vastag, 2019). Silymarin has curative applications such as hepatoprotection for over 2000 years (Mukhtaret al., 2021 and MacDonald-Ramoset al., 2021), anticarcinogenic effects (Fallahet al., 2021) and have diverse impacts on numerous organs, such as the liver, pancreas, and gastrointestinal tract, as well as a potent antioxidant against oxidative stress (Khazaeiet al., 2021). Silymarin also, has effect on hepatic cells as protein biosynthesis and cell regeneration were increased, as well as anti-lipid peroxidation properties, ability to scavenge oxygen free radical, stabilizing cell membrane (Yanget al., 2021), regulates the intracellular 
levels of the reduced GSH, chelates metal ions (iron and copper) (Bouhalit and Kechrid, 2018); promoter of ribosomal RNA synthesis (Khazaeiet al., 2021) and stimulation of protein synthesis, leading in the formation of new liver cells to replace those that have become damaged (Vargas-Mendozaet al.,2014).

Ionizing radiation is a high-energy radiation emitted by radionuclides, which are elements in unstable forms. It can cause structural changes leading to biological damage (Jiaet al., 2021). The severity of ionizing radiations relies on the kind, amount and density of radiation and period of exposure (Choudhary, 2018). Ionizing radiation consisted of both particles such as (electrons, protons, neutrons, beta and alpha) relying on their atomic characteristics and electromagnetic radiation (x-rays and $y$-rays) which are the most common electromagnetic radiation producing cellular modifications such as mutations, chromosome aberration and cellular damage (Tanaka and Furuta, 2021). Gammaradiation can lead to damage in two ways either directly or indirectly or by both effects. In direct interaction which is the main harmful effect by affecting the cell as a whole, either by killing the cell or mutating the DNA through hitting a cell's macromolecules such as proteins or DNA (Ahmed et al., 2020). Also, ionizing radiation affects indirectly, via the formation of free radicals which may either inactivate cellular mechanisms or interact with the genetic material (DNA) (Smithet al., 2017).

\section{Materials And Methods}

All experimental protocols were approved by scientific research ethics committee, Mansoura University, Egypt.

\section{Experimental animals:}

The procedure follows the National Institutes of Health's criteria (USA) and ARRIVE guidelines. In this experiment, fifty male albino rats (Rattusrattus) with an average weight of $130 \pm 5 \mathrm{~g}$ and the same age were procured from the Egyptian Organization for Biological Products and Vaccines in Helwan city. Rats were setteled in stainless steel cages in a room with an autonomously adjusted temperature $\left(22-25^{\circ} \mathrm{C}\right)$ and relative humidity of $55 \pm 5 \%$, with a 12-hour light-dark cycle and free access to commercial balanced feed and tap water.The rats were given human care, and the current study followed the instructions's guidelines.

\section{Silymarin drug:}

SEDICO (South Egypt Drug Industries Company) created Silymarin, which was bought. The experimental dose was dissolved in distilled water (70mg/kg body weight) (Mahmoudet al., 2019).

\section{Preparation of boneMarrow mesenchymal stem cells (BMSCs):}

Eight mature male albino rats weighing 130-140 g were used to isolate bone marrow mesenchymal stem cells. Isolated bone marrow mesenchymal stem cells (BMSCs) can adhere to plastic surfaces and expand easily during in vitro culture as follows: the animal was placed in an anaesthesia chamber and halothane was used to anaesthetize it for around five minutes. Place the animal on an operation table and use cervical dislocation to kill it. Remove the skin and muscles from the back limbs and cut off the femurs and tibias. Dissect the femurs and tibias and soak them in $70 \%$ isopropanol for a few seconds before transferring them to sterile Petri dishes with 1X D-PBS. The femurs and tibias were transferred to a $10 \mathrm{~cm}$ dish in a biosafety cabinet. Tweezers were used to hold each bone while the two ends were sliced open with a scissor. Fill a $3 \mathrm{ml}$ syringe with complete medium (CM) (Dulbecco's modified eagle's medium \{DMEM\} with 10\% fetal bovine serum $\{F B S\}, 1 \%$ Pen-Strep, and 1\% L-glutamine), then flush the marrow into a $50 \mathrm{ml}$ tube by inserting a $22 \mathrm{G}$ needle into one open end of the bone. Repeat for each bone 2-3 times.Spinnung down the cells once we have collecte from all of the marrows at $200 \mathrm{xg}$ and $4^{\circ} \mathrm{C}$ for 5 minutes. The supernatant was aspirated and the cells were resuspended in $25 \mathrm{~mL}$ of $\mathrm{CM}$. Four sterile petri dishes were used. Each of the four dishes dishes was seeded by $10 \mathrm{ml}$ cell suspension. For 4 weeks, the culture dishes were kept at $37^{\circ} \mathrm{C}, 5 \% \mathrm{CO}_{2}$ incubator. Every 2-3 days, the media was replaced. The adherent cells were trypsinized by applying $4-5 \mathrm{ml}$ trypsin-EDTA to each dish when the cells had reached roughly $90 \%$ confluency. The dishes 
were returned to the incubator and leaft there for 3 minutes to allow the cells to detach. The detached cells were washed in PBS to remove the trypsin-EDTA. The detachment cells were checked under a microscope on a regular basis. Cells became separated and rounded. The flask was shaked slightly to help the cells separation. This procedure should take no more than 5 minutes. Cell suspension was collected in a $15 \mathrm{ml}$ tube and cells were spinnded down for 5 minutes at $200 \mathrm{xg}$ and $4^{\circ} \mathrm{C}$. BMSCs were resuspended in FBS at a concentration of $1.4 \times 10^{7}$ cells $/ \mathrm{kg}$ in cell pellets (Almundarijet al., 2020).

\section{Irradiation:}

Rats were positioned in a specific intended well-ventilated acrylic chamber and the rats body at whole were exposed to 4 Gy (gray), by a dose rate of $0.713 \mathrm{rad} / \mathrm{sec}$ for $9.33 \mathrm{~min}$. from the biological irradiator cesium-137 source achieved by Egyptian Atomic Energy Authority (EAEA), Cairo, Egypt (Eshak and Osman, 2013).

\section{Experimental design:}

Rats were randomly assigned into seven groups (each with six animals) after a one-week acclimatisation period: The normal control (NC) group consisted of animals that were fed a typical diet without supplementation. For three weeks, the second group (SI) was given a commercial balanced diet along with an oral dose of silymarin (70 mg/ $\mathrm{kg}$ diluted in distilled water). The third group (ST) received a single dose of BMSCs (about $1.4 \times 10^{7} \mathrm{cells} / \mathrm{kg}$ ) injected into the tail vein. The fourth group (IRR) was given a total body dose of radiation (4Gy). The fifth group (SIR) received a single dose (4Gy) of radiation after receiving silymarin $(70 \mathrm{mg} / \mathrm{kg})$ orally for three days before to radiation exposure and continuing until the end of the experiment. The sixth group (STR) received a single dosage of BMSCs $\left(1.4 \times 10^{7} \mathrm{cells} / \mathrm{kg}\right)$ in the tail vein after being irradiated with a single dose of $4 \mathrm{~Gy}$. The seventh group (SSR) was given silymarin $(70 \mathrm{mg} / \mathrm{kg})$ orally for three days before to irradiation, and then a single dosage of BMSCs was injected into the tail vein after irradiation.

\section{Tissue sampling:}

By the end of experimental periods, rats were fasted for $12 \mathrm{hrs}$ then slaughtered by cervical dislocation after numbed by ether anesthesia. Livers were separated quickly, cleared from any particles and cut into pieces. Tissue samples from a definite fraction of the livers were weighed exactly and grind homogenously in a 10 - fold volume of ice - cold distilled water. The homogenates were centrifuged at $860 \mathrm{xg}$ for $20 \mathrm{~min}$. Finally the supernatants were separated and stored at $4^{\circ} \mathrm{C}$ until subsequent biochemical analysis. Another specimen of liver was weighed and kept at $-80^{\circ} \mathrm{C}$ for later molecular analysis.

\section{Biochemical analysis:}

Reduced glutathione (GSH) was evaluated in tissue homogenate based on the method adopted by Prins and Losse (1969). Glutathione-S-trasferase (GST) activity was assayed spectrophotometrically using 1-chloro-2-4dinitrobenzene (CDNB) and glutathione as described by Habiget al. (1974). Superoxide dismutase (SOD) activity was assayed as described by Nishikimiet al. (1972). Catalase (CAT) activity was determined according to the method of Bocket al.(1980), based on the ability of CAT to decompose $\mathrm{H}_{2} \mathrm{O}_{2}$. The level of malondialdehyde (MDA) was determined as thiobarbituric acid reactive substance (TBARS) according to the modified method of Ohkawaet al. (1979). The method of H2O2 concentration was carried out according to the colorimetric method of Aebi (1984). Glucose - 6- phosphate dehydrogenase (G-6-PDase) activity was estimated by the method of Kornberget al.(1955). While the total antioxidant capacity (TAC) in liver was determined according to the technique of Koracevicet al. (2001), using colorimetric kit purchased from Bio-diagnostic Company, Taher St., Dokki, and Giza, Egypt.

\section{Molecular analyses:}

\section{DNA extraction:}


Sections of liver were put in test tubes and washed twice with $10 \mathrm{ml}$ sterile deionized water by vortexing for two minutes, followed by centrifugation for 5 minutes and the supernatant was decanted. $2 \mathrm{ml}$ sterile deionized water was added to the washed tissue section and homogenized by tissue homogenizer. DNA extracted according to the following method of Gene jet genomic DNA purification kit supplied by Thermo Scientific Company (Elmohandsean, Cairo, Egypt).

\section{Random Amplified Polymorphic DNA-PCR (RAPD PCR): Williams et al. (1990):}

\section{a- Mixed primers}

$2 \mu \mathrm{g}$ of pure genomic DNA and $15 \mathrm{pm}$ of each primer (operon kit- B) are mixed with two PCR beads (to examine the kit efficiency), and the volume was completed to $50 \mu \mathrm{l}$ with sterile distilled water. The mixture was mixed by many inversions and collected again by spin at maximum speed in Eppendorf centrifuge for 5 seconds. Two drops of mineral oil was added.

b- Single primer of operon kit B in the mix.

$1 \mu \mathrm{g}$ of pure genomic DNA and $15 \mathrm{pm}$ of the selected primer Op B-10 or Op B-14 [that produced successful PCR reaction with stem cells and irradiated DNA samples (Table I); while the reminder of Op-B primers failed to produce successful PCR] were mixed with one PCR bead in $200 \mu \mathrm{l}$ sterile eppendorf and the final volume was completed to $25 \mu \mathrm{l}$ with sterile deionized water. The mixture was mixed by many inversions and collected again by spin at maximum speed in eppendorf centrifuge for 5 seconds. Two drops of mineral oil was added.

For primers amplification, PCR mixture was transferred to thermal cycler programmed for 35cycles as follows: 1 min at 94 ${ }^{\circ} \mathrm{C}$ for DNA denaturing, $1 \mathrm{~min}$ at $48{ }^{\circ} \mathrm{C}$ for annealing and $2 \mathrm{~min}$ at $72{ }^{\circ} \mathrm{C}$ for new DNA extension, followed by final DNA extension at $72{ }^{\circ} \mathrm{C}$ for $7 \mathrm{~min}$. PCR product and $1 \mathrm{kbp}$ DNA ladder (Gene Ruler ${ }^{\mathrm{m}}$ ) were mixed with bromophenol blue loading dye (6x) then analyzed by electrophoresis on $2 \%$ agarose gel mixed with star gel and electrophoresed at $80 \mathrm{~V}$ for $1 \mathrm{~h}$ and the amplified DNA bands were visualized under UV light (Sambrooket al., 1998).

Table I: Nucleotide sequences of Operon RAPD-PCR kit B 


\section{Statistical analysis}

\begin{tabular}{|ll|}
\hline Name & Sequence \\
\hline OP. B-07 & 5- GGTGACGCAG - 3 \\
\hline OP. B-08 & 5-GTCACACGG - 3 \\
\hline OP. B-09 & 5-TGGGGGACTC-3 \\
\hline OP. B-10 & 5-CTGCTGGGAC-3 \\
\hline OP. B-11 & 5-GTAGACCCGT-3 \\
\hline OP. B-12 & 5-CCTTGACGCA-3 \\
\hline OP. B-13 & 5-TTCCCCCGCT-3 \\
\hline OP. B-14 & 5-TCCGCTCTGG-3 \\
\hline OP. B-15 & 5-GGAGGGTGTT-3 \\
\hline OP. B-16 & 5-TTTGCCCGGA-3 \\
\hline OP. B-17 & 5-AGGGAACGAG-3 \\
\hline OP. B-18 & 5-CCACAGCAGT-3 \\
\hline OP. B-19 & 5-ACCCCCGAAG-3 \\
\hline
\end{tabular}

Using SPSS statistical package version 17.00 software, data were statistically analysed using one-way analysis of variance (One-way ANOVA) and post comparison with (LSD) test. The results were presented as means $\pm S E$, with $P \leq$ 0.05 being regarded statistically significant (Snedecor and Cochran, 1980).

\section{Results}

\section{1-Liver biochemical parameters results:}

As shown from the present findings, MSCs and silymarin groups are tended to exhibit significant elevation in GSH content, GST, SOD, CAT, TAC and G-6-PDase activities. This goes with significant reduction in LPOand $\mathrm{H}_{2} \mathrm{O}_{2}$ content in

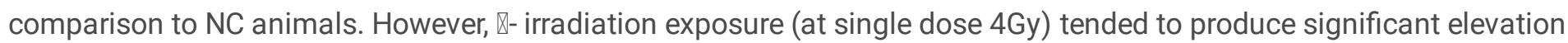
inhepatic values of $\mathrm{LPO}$ and $\mathrm{H}_{2} \mathrm{O}_{2}$ content accompanied with pronounced reduction in the measured antioxidant parameters compared to their respective NCgroups. On other hand, irradiated rats administrated silymarinor/ andMSCs succeeded to restore alterations in theses parameters comparing to their relative irradiated group with more evident effectswere obviously obsereved in most parameters after 3 weeks of treatment (Table 1). 
Table 1

liver tested biochemical parameters of both control and experimental groups.

\begin{tabular}{|c|c|c|c|c|c|c|c|c|}
\hline \multirow{2}{*}{\multicolumn{2}{|c|}{$\begin{array}{l}\text { Tested parameters } \\
\text { Liver }\end{array}$}} & \multicolumn{7}{|c|}{ Animal groups } \\
\hline & & NC & SI & ST & IRR & SIR & STR & SSR \\
\hline \multirow{4}{*}{$\begin{array}{l}\text { Reduced } \\
\text { glutathione } \\
\text { (GSH) } \\
\text { mg/100g wet } \\
\text { tissue }\end{array}$} & $\begin{array}{l}\text { One } \\
\text { week }\end{array}$ & $\begin{array}{l}22.63^{a} \pm \\
0.34\end{array}$ & $\begin{array}{l}32.88^{b} \pm \\
0.18\end{array}$ & $\begin{array}{l}26.66^{c} \pm \\
0.39\end{array}$ & $\begin{array}{l}8.96^{d} \pm \\
0.23\end{array}$ & $\begin{array}{l}15.95^{\text {efg }} \pm \\
1.09\end{array}$ & $\begin{array}{l}14.34^{\mathrm{ef}} \pm \\
0.93\end{array}$ & $\begin{array}{l}16.49^{e g} \pm \\
0.49\end{array}$ \\
\hline & & & +45.29 & -17.81 & -60.41 & -29.52 & -36.63 & -27.13 \\
\hline & $\begin{array}{l}\text { Three } \\
\text { weeks }\end{array}$ & $\begin{array}{l}28.59^{\mathrm{a}} \pm \\
0.10\end{array}$ & $\begin{array}{l}33.09^{b} \pm \\
0.78\end{array}$ & $\begin{array}{l}31.76^{b} \pm \\
0.42\end{array}$ & $\begin{array}{l}12.91^{c} \pm \\
0.85\end{array}$ & $\begin{array}{l}20.10^{d} \pm \\
0.41\end{array}$ & $\begin{array}{l}19.59^{d} \pm \\
0.45\end{array}$ & $\begin{array}{l}23.94^{\mathrm{e}} \pm \\
0.17\end{array}$ \\
\hline & & & +15.74 & +11.09 & -54.84 & -29.70 & -31.55 & -16.26 \\
\hline \multirow{4}{*}{$\begin{array}{l}\text { Glutathione-S- } \\
\text { trasferase } \\
\text { (GST) } \\
\mu \mathrm{mol} / \mathrm{min} . / \mathrm{g} \\
\text { wet tissue }\end{array}$} & $\begin{array}{l}\text { One } \\
\text { week }\end{array}$ & $\begin{array}{l}22.27^{a} \pm \\
0.34\end{array}$ & $\begin{array}{l}24.83^{b} \pm \\
0.41\end{array}$ & $\begin{array}{l}22.70^{\mathrm{a}} \pm \\
0.54\end{array}$ & $\begin{array}{l}10.17^{c} \pm \\
0.13\end{array}$ & $\begin{array}{l}17.10^{d} \pm \\
0.46\end{array}$ & $\begin{array}{l}19.88^{e} \pm \\
0.34\end{array}$ & $\begin{array}{l}19.93^{e} \pm \\
0.45\end{array}$ \\
\hline & & & +9.56 & +1.93 & -54.33 & -25.15 & -10.73 & -10.51 \\
\hline & $\begin{array}{l}\text { Three } \\
\text { weeks }\end{array}$ & $\begin{array}{l}29.76^{a} \pm \\
0.31\end{array}$ & $\begin{array}{l}35.28^{b} \pm \\
0.59\end{array}$ & $\begin{array}{l}33.97^{b} \pm \\
0.20\end{array}$ & $\begin{array}{l}15.92^{c} \pm \\
0.48\end{array}$ & $\begin{array}{l}25.02^{d} \pm \\
0.76\end{array}$ & $\begin{array}{l}26.50^{d} \pm \\
0.95\end{array}$ & $\begin{array}{l}28.98^{a} \pm \\
0.44\end{array}$ \\
\hline & & & +18.55 & +14.15 & -46.51 & -15.93 & -10.95 & -2.62 \\
\hline \multirow{4}{*}{$\begin{array}{l}\text { Superoxide } \\
\text { dismutase } \\
\text { (SOD) } \\
\text { U/g wet tissue }\end{array}$} & $\begin{array}{l}\text { One } \\
\text { week }\end{array}$ & $\begin{array}{l}138.47^{a} \pm \\
2.37\end{array}$ & $\begin{array}{l}168.87^{b} \pm \\
1.80\end{array}$ & $\begin{array}{l}147.40^{c} \pm \\
1.76\end{array}$ & $\begin{array}{l}90.54^{d} \pm \\
1.97\end{array}$ & $\begin{array}{l}104.80^{e} \pm \\
2.17\end{array}$ & $\begin{array}{l}99.05^{e} \pm \\
1.43\end{array}$ & $\begin{array}{l}105.28^{\mathrm{e}} \pm \\
1.06\end{array}$ \\
\hline & & & +21.95 & +6.45 & +34.61 & -24.32 & -28.47 & -23.97 \\
\hline & $\begin{array}{l}\text { Three } \\
\text { weeks }\end{array}$ & $\begin{array}{l}149.00^{\mathrm{a}} \pm \\
1.71\end{array}$ & $\begin{array}{l}174.87^{b} \pm \\
0.99\end{array}$ & $\begin{array}{l}169.54^{c} \pm \\
1.77\end{array}$ & $\begin{array}{l}78.63^{d} \pm \\
2.36\end{array}$ & $\begin{array}{l}126.69^{e} \pm \\
0.85\end{array}$ & $\begin{array}{l}120.70^{f} \pm \\
1.48\end{array}$ & $\begin{array}{l}131.15^{e} \pm \\
1.75\end{array}$ \\
\hline & & & +17.36 & +13.79 & -74.23 & -14.97 & -18.99 & -11.98 \\
\hline \multirow{4}{*}{$\begin{array}{l}\text { Catalase } \\
\text { (CAT) } \\
\text { ⿲mol/sec./g } \\
\text { wet tissue }\end{array}$} & $\begin{array}{l}\text { One } \\
\text { week }\end{array}$ & $\begin{array}{l}24.33^{a} \pm \\
0.85\end{array}$ & $\begin{array}{l}32.88^{b} \pm \\
0.43\end{array}$ & $\begin{array}{l}27.92^{C} \pm \\
0.06\end{array}$ & $\begin{array}{l}10.44^{d} \pm \\
0.75\end{array}$ & $\begin{array}{l}19.27^{e} \pm \\
0.15\end{array}$ & $\begin{array}{l}16.39^{f} \pm \\
0.58\end{array}$ & $\begin{array}{l}19.71^{e} \pm \\
0.52\end{array}$ \\
\hline & & & +35.14 & +14.76 & -57.09 & -20.80 & -32.63 & -18.99 \\
\hline & $\begin{array}{l}\text { Three } \\
\text { weeks }\end{array}$ & $\begin{array}{l}29.67^{\mathrm{a}} \pm \\
1.23\end{array}$ & $\begin{array}{l}39.95^{b} \pm \\
0.14\end{array}$ & $\begin{array}{l}37.82^{C} \pm \\
0.76\end{array}$ & $\begin{array}{l}16.54^{d} \pm \\
0.30\end{array}$ & $\begin{array}{l}25.78^{e} \pm \\
0.68\end{array}$ & $\begin{array}{l}23.45^{f} \pm \\
0.19\end{array}$ & $\begin{array}{l}27.83^{a} \pm \\
0.81\end{array}$ \\
\hline & & & +34.65 & +27.47 & -44.25 & -13.11 & -20.96 & -6.20 \\
\hline \multirow{2}{*}{$\begin{array}{l}\text { Glucose - 6- } \\
\text { phosphate } \\
\text { dehydrogenase } \\
\text { (G-6PD) }\end{array}$} & $\begin{array}{l}\text { One } \\
\text { week }\end{array}$ & $\begin{array}{l}35.88^{\mathrm{a}} \pm \\
0.49\end{array}$ & $\begin{array}{l}44.51^{b} \pm \\
1.11\end{array}$ & $\begin{array}{l}44.20^{b} \pm \\
0.60\end{array}$ & $\begin{array}{l}19.24^{c} \pm \\
0.13\end{array}$ & $\begin{array}{l}27.55^{d} \pm \\
1.28\end{array}$ & $\begin{array}{l}29.22^{\mathrm{de}} \pm \\
0.49\end{array}$ & $\begin{array}{l}30.95^{e} \pm \\
1.05\end{array}$ \\
\hline & & & +24.05 & +23.19 & -46.38 & -23.22 & -18.56 & -13.74 \\
\hline \multirow[t]{2}{*}{$\begin{array}{l}\mathrm{mU} / \mathrm{g} \text { wet } \\
\text { tissue }\end{array}$} & $\begin{array}{l}\text { Three } \\
\text { weeks }\end{array}$ & $\begin{array}{l}36.86^{\mathrm{a}} \pm \\
0.72\end{array}$ & $\begin{array}{l}42.23^{b} \pm \\
0.08\end{array}$ & $\begin{array}{l}45.56^{c} \pm \\
0.54\end{array}$ & $\begin{array}{l}13.69^{d} \pm \\
0.73\end{array}$ & $\begin{array}{l}32.61^{e} \pm \\
0.64\end{array}$ & $\begin{array}{l}33.41^{e} \pm \\
0.97^{2}\end{array}$ & $\begin{array}{l}34.24^{\mathrm{e}} \pm \\
1.06\end{array}$ \\
\hline & & & +14.57 & +23.68 & -62.86 & -11.53 & -9.36 & -7.11 \\
\hline \multirow{3}{*}{$\begin{array}{l}\text { Lipid } \\
\text { peroxidation } \\
\text { (LPO) } \\
\text { nmol/g wet } \\
\text { tissue }\end{array}$} & $\begin{array}{l}\text { One } \\
\text { week }\end{array}$ & $\begin{array}{l}226.39^{a} \pm \\
2.40\end{array}$ & $\begin{array}{l}186.24^{b} \pm \\
2.32\end{array}$ & $\begin{array}{l}179.15^{b} \pm \\
3.10^{-1}\end{array}$ & $\begin{array}{l}293.69^{c} \pm \\
2.07\end{array}$ & $\begin{array}{l}244.73^{d} \pm \\
4.58\end{array}$ & $\begin{array}{l}251.70^{d} \pm \\
3.24\end{array}$ & $\begin{array}{l}243.63^{d} \pm \\
1.55\end{array}$ \\
\hline & & & -17.73 & -20.87 & +29.73 & +8.10 & +11.18 & +7.62 \\
\hline & $\begin{array}{l}\text { Three } \\
\text { weeks }\end{array}$ & $\begin{array}{l}208.97^{\mathrm{a}} \pm \\
0.74\end{array}$ & $\begin{array}{l}184.09^{b} \pm \\
2.69\end{array}$ & $\begin{array}{l}160.11^{c} \pm \\
0.93\end{array}$ & $\begin{array}{l}269.10^{d} \pm \\
7.21\end{array}$ & $\begin{array}{l}236.86^{\mathrm{e}} \pm \\
3.36\end{array}$ & $\begin{array}{l}228.51^{e} \pm \\
1.82\end{array}$ & $\begin{array}{l}216.52^{a} \pm \\
2.73\end{array}$ \\
\hline
\end{tabular}




\begin{tabular}{|c|c|c|c|c|c|c|c|c|}
\hline & & & -11.91 & -23.38 & +28.77 & +13.35 & +9.35 & +3.61 \\
\hline \multirow{4}{*}{$\begin{array}{l}\text { Hydrogen } \\
\text { peroxide } \\
\left(\mathrm{H}_{2} \mathrm{O}_{2}\right) \\
\mathrm{mM} / \mathrm{g} \cdot \text { wet } \\
\text { tissue }\end{array}$} & \multirow[t]{2}{*}{$\begin{array}{l}\text { One } \\
\text { week }\end{array}$} & \multirow[t]{2}{*}{$\begin{array}{l}0.23^{a} \pm \\
0.002\end{array}$} & $\begin{array}{l}0.17^{b} \pm \\
0.002\end{array}$ & $\begin{array}{l}0.17^{b} \pm \\
0.003\end{array}$ & $\begin{array}{l}0.41^{c} \pm \\
0.01\end{array}$ & $\begin{array}{l}0.25^{\mathrm{a}} \pm \\
0.01\end{array}$ & $\begin{array}{l}0.30^{d} \pm \\
0.02\end{array}$ & $\begin{array}{l}0.26^{\mathrm{a}} \pm \\
0.004\end{array}$ \\
\hline & & & -28.51 & -26.81 & +72.77 & +7.66 & +26.81 & +8.94 \\
\hline & \multirow[t]{2}{*}{$\begin{array}{l}\text { Three } \\
\text { weeks }\end{array}$} & \multirow[t]{2}{*}{$\begin{array}{l}0.25^{a} \pm \\
0.003\end{array}$} & $\begin{array}{l}0.22^{b} \pm \\
0.01\end{array}$ & $\begin{array}{l}0.22^{c} \pm \\
0.002^{2}\end{array}$ & $\begin{array}{l}0.40^{d} \pm \\
0.01\end{array}$ & $\begin{array}{l}0.31^{e} \pm \\
0.01\end{array}$ & $\begin{array}{l}0.30^{e} \pm \\
0.01\end{array}$ & $\begin{array}{l}0.27^{a} \pm \\
0.01\end{array}$ \\
\hline & & & -14.51 & -15.69 & +58.04 & +20.78 & +17.65 & +5.88 \\
\hline \multirow{4}{*}{$\begin{array}{l}\text { Total } \\
\text { antioxidant } \\
\text { capacity } \\
\text { (TAC) } \\
\mathrm{ng} / \mathrm{g} \text { wet } \\
\text { tissue }\end{array}$} & \multirow[t]{2}{*}{$\begin{array}{l}\text { One } \\
\text { week }\end{array}$} & \multirow[t]{2}{*}{$\begin{array}{l}21.61^{a} \pm \\
0.28\end{array}$} & $\begin{array}{l}34.27^{b} \pm \\
0.61\end{array}$ & $\begin{array}{l}29.23^{c} \pm \\
0.37\end{array}$ & $\begin{array}{l}11.75^{d} \pm \\
0.68\end{array}$ & $\begin{array}{l}17.40^{\mathrm{e}} \pm \\
0.22\end{array}$ & $\begin{array}{l}16.05^{f} \pm \\
0.21\end{array}$ & $\begin{array}{l}19.87^{9} \pm \\
0.20\end{array}$ \\
\hline & & & +58.58 & +35.26 & -45.63 & -19.48 & -25.73 & -8.05 \\
\hline & \multirow[t]{2}{*}{$\begin{array}{l}\text { Three } \\
\text { weeks }\end{array}$} & \multirow[t]{2}{*}{$\begin{array}{l}25.44^{a} \pm \\
0.30\end{array}$} & $\begin{array}{l}40.16^{b} \pm \\
0.11\end{array}$ & $\begin{array}{l}39.52^{b} \pm \\
0.44\end{array}$ & $\begin{array}{l}15.40^{c} \pm \\
0.48\end{array}$ & $\begin{array}{l}24.48^{a} \pm \\
0.75\end{array}$ & $\begin{array}{l}24.53^{a} \pm \\
0.63\end{array}$ & $\begin{array}{l}25.38^{a} \pm \\
0.58\end{array}$ \\
\hline & & & +57.86 & +55.35 & -39.47 & -3.77 & -3.58 & -0.24 \\
\hline
\end{tabular}

Results are presented as mean \pm SE (n of 6 rats for each group) and \% of change as compared to respective control group.

-Values superscripts with different letters. (a-g) were significantly different $(P \leq 0.05)$, but with the same letters were insignificantly different.

NC: normal control SI: Silymarin ST: Stem cells IRR: Irradiated with gamma

SIR: Silymarin + irradiated STR: Stem cells + irradiated SSR: Silymarin + Stem cells + irradiated.

\section{2- Molecular Results:}

Genomic DNA of liver tissues of treated and control animals after one and three weeks were successfully extracted at a molecular weight 20kpb (Fig. 1a \&1b). Random Amplified Polymorphic DNA-PCR (RAPD-PCR) of genomic DNA is performed as a genetic marker.

\section{Figure 1a}

Agarose gel electrophoresis of genomic DNA of liver tissue in different groups after one week. Lane 1 is control (NC), lanes 2 is silymarin (SI), lanes 3, 4 are stem cells (ST), lanes 5, 6 are irradiated (IRR), lanes 7, 8 are irradiated with silymarin ( SIR), lanes 9, 10 are irradiated with stem cells (STR) and lanes 11, 12 are silymarin plus stem cell in irradiated groups( SSR) respectively. Lane M (right) is 100 bp ladder "100-3000 bp" DNA marker, while lane M (left) is $1 \mathrm{~K}$ bp ladder "100- 10000 bp" DNA marker.

RAPD-PCR analysis carried out on the selected DNA liver samples of treated and control animal groups after one and three weeks to investigate the presence and/or absence of definite bands when comparing the normal RAPD-PCR pattern with RAPD- PCR patterns of other treated groups using the OP-B10 and OP-B14 primers and the results are documented in Fig. 2a\& 2b. After one week of treatment RAPD-PCR with primer OP-B10 produced two control marker bands in normal control sample (NC) and silymarin group (SI) at molecular weights 4000 and 950 base pair. While, DNAs of control stem cells (ST) group, irradiated rats treated with silymarin (SIR) and irradiated rats treated stem cells (STR) produced one control marker band only (4000 bp) and the second control marker band (950 bp) is disappeared. Moreover, irradiated group (IRR) appeared two new bands (1650 and 2000 bp) beside one control marker band (4000 bp) and disappearing of the second control marker (band $950 \mathrm{bp}$ ). Silymarin plus stem cell in irradiated groups (SSR) produced one normal marker band $4000 \mathrm{bp}$ and appearing of a new band (2150bp), while the second control marker band (950 bp) is disappeared. 
After three weeks RAPD-PCR of NC group was amplified using primer OP-B10 and one major control marker band at molecular weights 4000 bps is appeared. ST, STR and SSR groups produced the same profile of NC group. RAPD-PCR of SI group produced the same control marker band (4000 bp) and another new band (1000 bp) is appeared. Similarly, RAPD-PCR of IRR group produced the same marker normal control band (4000 bp) and another new band (1650bp) is appeared. On other hand, SIR produced two new bands 950 and $2500 \mathrm{bp}$ and the major control marker band is disappeared (Fig. 2a).

Moreover, The RAPD-PCR with primer OP-B14 after one week produced two marker control bands which appeared in NC samples at molecular weights 4000 and 1000 base pair. While, the RAPD-PCR of SI group produced one marker control band (4000bp) and another new band (1200 bp) is appeared.On the other hand ST group produced news even major bands (3000, 2500, 2000, 1700, 1500, 1300 and 1200 bps) and the two marker control bands are disappeared. Moreover IRR group, the two marker control bands are disappeared and one new band (1300 bp) is appeared. In case of RAPD-PCR of SIR group, one new band (1500 bp) is appeared and one marker control band (4000bp) is appeared while the second control band (100 bp) is disappeared. STR and SSR groups RAPD-PCR produced new five bands $(3000,2500,2000,1700$ and $1500 \mathrm{bps}$ ) beside one marker control band (4000bp) while the second control band (100 bp) is disappeared. Also, the RAPD-PCR of NC group after hre weeks was amplified using primer OP-B14; one major normal control marker band with molecular weights $1000 \mathrm{bp}$ is appeared. Whereas, RAPD-PCR product of SI group produced one new band (1500 bp) while the normal control marker band (1000 bp) is disappeared. In ST group the normal control marker band (1000 bp) is disappeared and a new five band (2600, 2500, 2000, 1700 and 1500 bps) are appeared. Also, in case of RAPD-PCR of IRR group did not have any bands when comparing with NC group. On other hand, SIR group the normal control marker band (1000 bp) is disappeared and a new one band (1300 bps) is appeared. While, STR and SSR groups produced the same ST banding pattern profile in which the normal control marker band (1000 bp) is disappeared and a new five band (2600, 2500, 2000, 1700 and 1500 bps) are appeared (Fig. 2b).

\section{Discussion}

lonizing radiations are recognized to stimulate oxidative stress by the production of reactive oxygen species (ROS) such as superoxide $\left(\mathrm{O}_{2} \cdot \llbracket\right),(\mathrm{OH} \cdot)$ and hydrogen peroxide $\left(\mathrm{H}_{2} \mathrm{O}_{2}\right)$ (Jameel and Mohammed, 2021) causing a lopsidedness in the prooxidants and antioxidants in the cells (Nasret al., 2020). Numerous mechanisms may cause cellular injury after radiation exposure but the formation of oxygen free radicals followed by LPO which may be one of the main reasons in the sequential of events (Wanget al., 2019). Radiation generates ROS that combined with cellular molecules, including DNA, lipids, and proteins (Jiaet al., 2021).

The current data registered a pronounced decline in the antioxidant defense system concomitant with the growing lipid and hydrogen peroxides levels in liver tissues following y-radiation exposure. In compatible with the present study of Zakaria2017; Sarhan and Naoum 2020 who registered a decline in the activities of SOD, GST and GSH content which may be due to the formation of ROS that reacst with the enzymes molecules causing denaturation and limited inactivation of enzymes. Under ordinary situations, lipid peroxidation occurs in narrow range in body tissues while, the exaggerated formation of free radicals forming peroxidative modifications that at the end promotes LPO (Sacket al., 2017; Akhigbe and Ajayi, 2021), which is ascribed to the oxidation of the polyunsaturated fatty acids by generation of free radical causing structure and function modifications to molecules cellular membrane by direct way, through transporting energy or by indirect way, through formation of dominant oxygen derived free radical $(\mathrm{OH} \cdot)$, superoxide $\left(\mathrm{O}_{2} \cdot \rrbracket_{)}\right)$and nitric oxide $\left(\mathrm{NO}^{-}\right)$(Abd-Ellatefet al., 2017 and luchiet al., 2019) or to the deficiency in antioxidants levels which have the ability to hunt peroxy radicals after radiation exposure (Forman and Zhang, 2021).

Also, Sun et al.(2018) and Olivareset al.(2020) reported that radiation exposure exhibited decline in GSH content through minimizing the efficacy of GSH-Rx or reducing the activity of G-6-PD leading to scarcity of NADPH which is essential to

Page 9/20 
modify oxidized glutathione (GSSG) to its reduced form GSH (Xionget al., 2020) or through oxidative stress which caused a decrease in glutamate levels, which has been estimated to be in relation with decline intracellular GSH levels, as GSH vied with glutamate for the glutamate binding site of the gamma glutamyl cysteine synthetase, the primary and controlling step of GSH synthesis or caused malfunction of cellular membranes uncontrolling GSH mobilization (Formanet al., 2009) or elevated the usage of GSH (acts a reductant for peroxides and free radicals) to neutralize the excess of free radicals (Olivareset al., 2020).

Besides, the current work showed that irradiated rats exhibited a pronounced reduction in the efficacy of hepatic antioxidant enzymes such as SOD and CAT. The reported decline in SOD efficiency is probably due to rise of $\mathrm{O}_{2 \cdot \mathbb{V}}$ generation or suppression by the $\mathrm{H}_{2} \mathrm{O}_{2}$, which results in the reduction in the CAT efficacy, which is responsible for degeneration of $\mathrm{H}_{2} \mathrm{O}_{2}$ (Wang et al., 2018). While, decline in CAT efficiency may be a result of excessive usage to face off LPO formation, besides detoxifying $\mathrm{H}_{2} \mathrm{O}_{2}$ into $\mathrm{H}_{2} \mathrm{O}$ and $\mathrm{O}_{2}$ (Rajputet al., 2021). Another related finding, the present study showed that RAPD-PCR analysis succeeded in demonstration of the genetic damages induced by irradiation (IRR) by using of both primers OP-B10 and OP-B14 in one and three weeks periods. RAPD-PCR pattern with OP-B10 primer of whole body $\mathrm{Y}$-irradiated rats at $4 \mathrm{~Gy}$ after one week produced differences represented in disappearing of half of the marker bands. While, additional new bands beside the control marker bands are appeared in the irradiated group after three weeks of treatment. This goes in agreement with Ahmed et al. 2020 who suggested that the vanishing or emrging of an amplified RAPD segment is most likely due to DNA damage and mutations at the primer-template interaction point, as well as unfair mitotic recombination or other structural effects that have sped up primer hybridization.

Also, $y$-radiation can induce cellular DNA damage by both straight and vicarious ways. Straight way inducing by destruction of chemical bonds in DNA molecules, while vicarious way resulting by the formation of ROS such as $\mathrm{OH}^{\circ}$ and $\mathrm{O}_{2} \otimes$ radical leading to DNA fragmentation by causing single- and double-stranded DNA breaks, mutations and LPO leading to cellular injury causing cellular death (Ahmedet al. 2020).

On other hand, the present results showed that, MSCs/BM extract; markedly inhibited the harmful effect of $y$-radiation on antioxidant defense system. As it reduced LPO in parallel with elevated the efficacy of CAT, SOD and GSH-Px in liver tissue. The in vivo protection and particular replies of MSCs to oxidative stress may act an important role in adjusting tissue homeostasis as well as renewal of tissues after oxidative damage (Sagaradzeet al., 2020 and Yanet al., 2021) through a straight hunting and deactivation of the free radical or production of the endogenous antioxidant enzymes such as CAT and SOD. Angeloniet al. 2020 Showed that MSCs implantation could restore the imbalance between ROS and the antioxidant defense system by elevating the antioxidant capacity as well as modifying LPO.

Also, In other researches human MSCs transplantation markedly reduced oxidative stress following radiation exposure (Huet al., 2019) by inducing a transcription factor, nuclear related factor 2 (Nrf2) which is essentially adjusted the main and inducible level of cytoprotective genes. Its activation is a type of protection against oxidative stress through SOD production leading to ROS reduction in liver (Zhouet al., 2020).

In addition, the current results showed that MSCs usage is highly succeeded in healing the decomposition of cells DNA of the irradiated rats (STR) when it used alone or with silymarin supplement (SSR). The results reflects the greet efficiency of the MSCs when it used alone or combined with silymarin supplement in repairing the genetic changes due to irradiation. In agreement with this Vazet al. 2021 who showed that BM/MSCs pretreatment were markedly reduced the number of cells with chromosomal mutations and exhibited the perfect outcomes by reducing chromosomal mutations towards the normal, but still markedly elevated when compared to healthy control group. This explained as MSCs can restore alterations in DNA genome and keep the liver tissues safe from apoptosis following y-radiation exposure (Ezqueret al., 2017). This defense is multifactorial including modifying the oxidative stress reaction, organ injury and renovation. 
Moreover, Natural antioxidants have a constantly and essential role for inhibition of ROS, with keeping little amount important to adjust normal cell function (Azizet al., 2019). Along with this, the present study showed that silymarin administration prior to exposure of rats to ionizing radiation greatly normalized all the hepatic antioxidant parameters such as SOD, CAT, and GST as well as LPO and $\mathrm{H}_{2} \mathrm{O}_{2}$ levels. The present results are in line with previous studies of Abdelazim 2017; Al-Hazmi 2020 and Ghonaimet al.,(2021) who showed the very antioxidant capacity of silymarin which is eligible for catching ROS.

This could be through silymarin elevation of the antioxidant potential of cells by improving the harmful effects of free radical reactions (El-Maddawy \& Gad, 2012 and Farajiet al., 2019), protect hepatocytes (and other cells in the body and brain) from free radical reactions by catching of free radicals such as $\mathrm{OH}^{-}$type (Gillessen and Schmidt, 2020) with an effect on DNA-expression through inhibition of nuclear factor NF- B \& inhibiting LPO (Li et al., 2012), stimulates hepatocytes protein production and reduces the oxidation of GSH (Kwon et al., 2013). Moreover, silymarin has metabolic and cell adjusting effects, called carrier mediated regulation of the fluidity of hepatocytes microsomes and the liver mitochondrial membrane (Vahabzadehet al., 2018).

Additionally, the present results showed that silymarin supplementation (SI) itself succeeded in producing a banding profile identical to the control after one week only, but it produced a negative effect by damaging the DNA when the period prolonged to three weeks. While, it produced a profile near to the control groups in silymarin treated irradiated rats after one week only. This goes in agreement with El Mesallamyet al. 2011 and Adhikariet al. 2013 who showed that silymarin administered $1 \mathrm{hr}$ before irradiation (moderated radiation) and for 7 and 14 days following $Y$-irradiation induced changes in nucleic acids in its target organs; liver, spleen and bone marrow through producing modifications in RNA and DNA concentrations and inhibit nuclear DNA injury in male rats.

Moreover, silymarin regulates lopsidedness between cell regeneration and cell death through interfering with the expressions of cell cycle controllers and proteins implicated in cell death (Kimet al., 2021). Silymarin reacts with the estradiol receptor and activate it in the hepatocytes cells, and the activated receptor could elevate the liver endonuclear RNA polymerase I efficacy and the number of ribosomes in intracytoplasm, activate the transcription of ribosome RNA and the production of enzyme, structure protein and cellular DNA indirectly, which are useful to hepatic cytothesis (Karimiet al., 2011; and Hajiaghamohammadiet al., 2012).

\section{Conclusion}

Whole body gamma radiation exposure exhibited a harmful effect on liver antioxidant defense system and liver DNA molecules. While treatment with a natural antioxidant such as silymarin with transplanted MSCs improved these changes So we recommended adminstration of silymarin pre and post gamma radiation exposure beside MSCs transplantation which showed a pronounced effect together towards changes in antioxidant defense system and liver DNA mutation.

\section{Declarations}

We declare that the present research paper is our original work and no part of it has been published anywhere else in the past.

\section{- Ethical Approval and Consent to participate}

The study is ethically approved.

\section{- Human Ethics and Animal Ethics}

The research is carried out on male albino rats according to the basal declaration society outlines. 


\section{- Consent for publication}

Not applicable

\section{- Availability of supporting data}

We confirm that the data supporting the findings of this study are available within the article and its supplementary materials.

\section{- Competing interests}

We declare that we have no competing interests in the subject matter or materials discussed in this manuscript but it is a personal competing interest.

\section{- Funding}

We declare that we don't have any funder; but we are self funders.

\section{- Authors' contributions}

Dr/Ashraf Z. Mahmoud wrote the manuscript and performed the analysis and Dr/ M. R. El-Sawi conceived \& designed the analysis, while Dr/ M. N. Habza collected the data. All the authors reviewed the manuscript.

\section{- Acknowledgements}

Sincerely, extended to all of the zoology department stuff and technicians; faculty of science, Mansoura University, Egypt.

\section{- Authors' information}

\section{Ashraf Z. Mahmoud (corresponding author)}

Email : ashrafzakaria@mans.edu.eg

Alternative email: ashrafzakaria7878@yahoo.com

Affilation: Urology and Nephrology Center, Mansoura University, Mansoura, Egypt.

Orcid: https://orcid.org/0000-0001-8490-8048

Associate professor of molecular cell biology and associate consultant of medical analysis at Urology and nephrology center, Mansoura University, Egypt. The interested research area is the molecular biology studies of different types of cancers. Author and coauthor in many of published local and ranked international journals since 1998 till now.

\section{R. El-Sawi}

Email: mel_sawi@mans.edu.eg

Affilation: Zoology department, faculty of science, Mansoura university, Egypt.

Professor of animal physiology \& ecology, zoology department, faculty of science, Mansoura University, Egypt. The main specialization is radiology. Participated in many scientific workshops like; endnote program, stem cells and radiology. Author and co-author in many of published local and international journals since 1986 till now. 
Email: mero20037@yahoo.com

Affilation: Chemical laboratory, EL- Mahalla EL- Kubra, ministry of health, Egypt.

PhD, physiology \& ecology. Participated in different scientific workshops like; endnote program and stem cells extraction.

\section{References}

1. Abdelazim, A. S. (2017): Effect of silymarin as natural antioxidants and antimicrobial activity. Egyptian Journal of Agricultural Research, 95(2): 725-737.

2. Abd-Ellatef, G. E. F.; Ahmed, O. M.; Abdel-Reheim, E. S. and Abdel-Hamid, A. H. Z. (2017): Ulvalactuca polysaccharides prevent wistar rat breast carcinogenesis through the augmentation of apoptosis, enhancement of antioxidant defense system, and suppression of inflammation. Breast Cancer: Targets andTherapy, 9: 67-83.

3. Abdullah, H. and Alshammary, S. (2020): Therapeutic application of stem cells in diabetes. Journal of Stem Cell Research \& Therapeutics, 6 (1): 23-30.

4. Adhikari, M.; Dhaker, A.; Adhikari, J.; Ivanov, V.; Singh, V.; Chawla, R.; Kumar, R.; Sharma, R.; Karamalakova, Y.; Gadjeva, V. and Arora, R. (2013): In vitro studies on radioprotective efficacy of silymarin against $y$-irradiation. International journal of radiation biology, 89(3): 200-211.

5. Aebi, H. (1984): Catalase in vitro. Methods in Enzymology, 105: 121-126.

6. Ahmed, A. Q.; Salman, A. Y.; Hassan, A. B.; Abojassim, A. A.; Mraity, H. A. A. and Jasim, M A.(2020): The impact of gamma ray on DNA molecule. International Journal of Radiology and Radiation Oncology, 6(1): 011-013.

7. Akhigbe, R. and Ajayi, A. (2021): The impact of reactive oxygen species in the development of cardiometabolic disorders: a review. Lipids in Health and Disease, 20(1): 1-18.

8. Al-Hazmi, A. (2020): Antioxidant Activity of Silymarin in Microcystin-LR cardiac and pulmonary induced injuries on mice. Pakistan Journal of Biological Sciences, 23(11): 1369-1373.

9. Almundarij, T. I.; Zaki, A. K. A.; Alharbi, Y. M.; Albarrak, S. M.; Alqarawi, T. S. and Abo-Aziza, F. A. M. (2020): Effect of silymarin and/or bone marrow-derived mesenchymal stem cells on carbon tetrachloride-induced hepatotoxicity in rats. Systematic Reviews in Pharmacy, 11(11):1654-1665.

10. Angeloni, C.; Gatti, M.; Prata, C.; Hrelia, S. and Maraldi, T. (2020): Role of mesenchymal stem cells in counteracting oxidative stress related neurodegeneration. International journal of molecular sciences, 21(9): 3299.

11. Aziz, M. A.; Diab, A. S. and Mohammed, A. A. (2019): Antioxidant categories and mode of action.

12. Azoz, S. N.; Farag, H. M. and Salama, A. M. (2019): Comparative botanical studies two varieties of Silybummarianum (L.) Gaertn.(Asteraceae) in Egypt.International Journal of Advanced Research in Biological Sciences, 6(6):154-168.

13. Böck, P.; Kramar, R.; Pavelka, M. and Böck-Kramar-Pavelka (1980): Peroxisomes and related particles in animal tissues. WienNew York: Springer, 7: 44-74.

14. Bouhalit, S. and Kechrid, Z. (2018): Protective effect of silymarin extracted from silybummarianum seeds upon nickelinduced hepatotoxicity in albino wistar rats. Annals of Microbiology and Immunology, 1 (1):1005.

15. Chen, S., Du, K. and Zou, C. (2020): Current progress in stem cell therapy for type 1 diabetes mellitus. Stem Cell Research \& Therapy, 11(1): (1-13).

16. Choudhary, S. (2018): Deterministic and stochastic effects of radiation. Cancer Therapy and Oncology International Journal, 12(2):31-32.

17. Dessie, G.; Molla, M. D.; Shibabaw, T. and Ayelign, B. (2020): Role of stem-cell transplantation in leukemia treatment. Stem Cells and Cloning: Advances and Applications: 13: (67-77). 
18. El Mesallamy, H. O.; Metwally, N. S.; Soliman, M. S.; Ahmed, K. A. and Moaty, M. M. A. (2011): The chemopreventive effect of Ginkgo biloba and Silybummarianum extracts on hepatocarcinogenesis in rats. Cancer Cell International, 11(1): 38.

19. El-Maddawy, Z. K. and Gad, S. B. (2012):Hepato-renal protection of silymarin in comparison with vitamin E in rats. Global Journal ofPharmacology, 6(3): 236-244.

20. Eshak, M. G. and Osman, H. F. (2013): Role of Moringaoleifera leaves on biochemical and genetical alterations in irradiated male rats. Middle-East J Sci Res, 16(10): 1303-1315.

21. Ezquer, F.; Bahamonde, J.; Huang, Y. L. and Ezquer, M. (2017): Administration of multipotentmesenchymal stromal cells restores liver regeneration and improves liver function in obese mice with hepatic steatosis after partial hepatectomy. Stem cell research and therapy, 8(1): 1-18.

22. Fallah, M.; Davoodvandi, A.; Nikmanzar, S.; Aghili, S.; Mohammad, S.; Mirazimi, A.; Aschner, M.; Rashidian, A.; Hamblin, M. R.; Chamanara, M.; Naghsh, N. and Mirzaei, H. (2021):Silymarin (milk thistle extract) as a therapeutic agent in gastrointestinal cancer. Biomedicine and Pharmacotherapy, 142(112024).

23. Faraji, T.; Momeni, H. R. and Malmir, M. (2019): Protective effects of silymarin on testis histopathology, oxidative stress indicators, antioxidant defence enzymes and serum testosterone in cadmium- treated mice. Andrologia, 51(5): e13242.

24. Forman, H. J. and Zhang, H. (2021): Targeting oxidative stress in disease: promise and limitations of antioxidant therapy. Nature Reviews Drug Discovery, 20: 689-709.

25. Forman, H. J.; Zhang, H. and Rinna, A. (2009): Glutathione: Overview of its protective roles, measurement, and biosynthesis. Molecular aspects of medicine, 30(1-2): 1-12.

26. Ghonaim, A. H.; AboElnaga, T.; Hopo, M. G.; Elgawish, R. A.; Abdou, R. H. and Elhady, K. A. (2021): Antioxidant capacity and hepatoprotective effect of silymarin against salinomycin-induced Toxicity in Adult Rabbits. Research square:1-16.

27. Gillessen, A. and Schmidt, H. H. J. (2020):Silymarin as supportive treatment in liver diseases: A narrative review. Advances in therapy, 37(4): 1279-1301.

28. Guo, Y.; Yu, Y.; Hu, S.; Chen, Y. and Shen, Z. (2020): The therapeutic potential of mesenchymal stem cells for cardiovascular diseases.Cell Death \& Disease, 11(5|):1-10.

29. Habig, W. H.; Pabst, M. J. and Jakoby, W. B. (1974): Glutathione S-transferases the first enzymatic step in mercapturic acid formation. Journal of Biological Chemistry, 249(22): 7130-7139.

30. Hajiaghamohammadi, A. A.; Ziaee, A.; Oveisi, S. and Masroor, H. (2012): Effects of metformin, pioglitazone, and silymarin treatment on non-alcoholic Fatty liver disease: a randomized controlled pilot study. Hepatitis monthly, 12(8).

31. Hu, L.; Zhang, Y.; Miao, W. and Cheng, T. (2019): Reactive oxygen species and Nrf2: functional and transcriptional regulators of hematopoiesis. Oxidative medicine and cellular longevity.

32. Iuchi, K.; Ema, M.; Suzuki, M.; Yokoyama, C. and Hisatomi, H. (2019): Oxidized unsaturated fatty acids induce apoptotic cell death in cultured cells. Molecular Medicine Reports, 19(4): 2767-2773.

33. Jameel, Q. Y. and Mohammed, N. K. (2021): Protective rules of natural antioxidants against gamma-induced damage -A review. Food Science and Nutrition, 9(9): 5263-5278.

34. Jia, C.; Wang, Q.; Yao, X. and Yang, J. (2021): The role of DNA damage induced by low/high dose ionizing radiation in cell carcinogenesis. Exploratory Research and Hypothesis in Medicine.

35. Karimi, G.; Vahabzadeh, M.; Lari, P.; Rashedinia, M. and Moshiri, M. (2011): “Silymarin”, a promising pharmacological agent for treatment of diseases. Iranian journal of basic medical sciences, 14(4): 308. 
36. Kaurinovic, B. and Vastag, D. (2019): Flavonoids and phenolic acids as potential natural antioxidants. In Antioxidants (pp. 1-20). London, UK: IntechOpen.

37. Khazaei, R.; Seidavi, A. and Bouyeh, M. (2021): A review on the mechanisms of the effect of silymarin in milk thistle (Silybummarianum) on some laboratory animals. Veterinary Medicine and Science, 1-13.

38. Kim, S. H.; Choo, G. S.; Yoo, E. S.; Woo, J. S.; Lee, J. H.; Han, S. H.; JUNG, S.H.; KIM, H. J. and Jung, J. Y. (2021):Silymarin inhibits proliferation of human breast cancer cells via regulation of the MAPK signaling pathway and induction of apoptosis. Oncology Letters, 21(6): 1-10.

39. Koracevic, D.; Koracevic, G.; Djordjevic, V.; Andrejevic, S. andCosic, V. (2001):Method for the measurement of antioxidant activity in human fluids. Journal of Clinical Pathology, 54(5): 356-361.

40. Kornberg, A.; Horecker, B.L. and Smyrniotis, P.Z. (1955): [42]Glucose-6-phosphate dehydrogenase 6-phosphogluconic dehydrogenase. Methods in Enzymology,1: 323-327.

41. Kwon, D.Y.; Jung, Y. S.; Kim, S. J.; Kim, Y. S.; Choi, D. W. and Kim, Y. C. (2013): Alterations in sulfur amino acid metabolism in mice treated with silymarin: a novel mechanism of its action involved in enhancement of the antioxidant defense in liver. Plantamedica, 79(12): 997-1002.

42. Lee, S. M.; Lee, S. D.; Wang, S. Z.; Sarkar, D.; Lee, H. M.; Khan, A.; Bhati, C.; Sharma, A.; Kumaran.; Bruno, D.; Adrian Cotterell, A. and Levy, M. F.(2021): Effect of mesenchymal stem cell in liver regeneration and clinical applications. Hepatoma Research, 7:53.

43. Li, C. C.; Hsiang, C. Y.; Wu, S. L. and Ho, T. Y. (2012): Identification of novel mechanisms of silymarin on the carbon tetrachloride-induced liver fibrosis in mice by nuclear factor-KB bioluminescent imaging-guided transcriptomic analysis. Food and Chemical Toxicology, 50(5): 1568-1575.

44. Liu, Z. and Cheung, H. H. (2020): Stem cell-based therapies for parkinson disease. International Journal Molecular Sciences, 21(21): 8060.

45. Lourenço, S. C.; Moldão-Martins, M.andAlves, V. D. (2019): Antioxidants of natural plant origins: from sources to food industry applications. Molecules, 24(22): 4132.

46. MacDonald-Ramos, K.; Michan, L.; Martinez-Ibarra, A. and Cerbon, M. (2021):Silymarin is an ally against insulin resistance: A review. Annals of Hepatology, 23:100255.

47. Mahmoud, A. Z.; Ibrahim, H. A.; El-Sawi, M. R. and Habza, M. N. (2020): Effects of silymarin and mesenchymal stem cells on hematological and some biochemical changes induced by gamma radiation in albino rats. International journal of radiation biology, 96(2): 220-227.

48. Mukhtar, S.; Xiaoxiong, Z.; Qamer, S.; Saad, M.; Mubarik, M. S.; Mahmoud, A. H. and Mohammed, O. B. (2021): Hepatoprotective activity of silymarin encapsulation against hepatic damage in albino rats. Saudi Journal of Biological Sciences, 28(1): 717-723.

49. Nasr, M.; Abdelhay, W. M. and Elbana, A. K. (2020): Possible protective role of aphanizomenonflos-aquae (AFA) food supplement against cerebellum neuronal injury induced by gamma radiation (histological, histochemical and immunohistochemical study). Al-Azhar International Medical Journal, 1(4):203-213.

50. Nishikimi, M.; Appaji, N. and Yagi, K. (1972): The occurrence of superoxide anion in the reaction of reduced phenazinemethosulfate and molecular oxygen. Biochemical and Biophysical ResearchCommunications, 46 (2): $849-$ 854.

51. Ohkawa, H.; Ohishi, N. and Yagi, K. (1979): Assay for lipid peroxides in animal tissues by thiobarbituric acid reaction. AnalyticalBiochemistry, 95(2): 351-358.

52. Olivares, A.; Alcaraz-Saura, M.; Achel, D. G. and Alcaraz, M. (2020): Effect of rosmarinic acid and ionizing radiation on glutathione in melanoma B16F10 cells: a translational opportunity. Antioxidants, 9(12): 1291. 
53. Pittenger, M. F.; Discher, D. E.; Péault, B. M.; Phinney,D. G.; Hare, J. M. and Caplan, A. I. (2019): Mesenchymal stem cell perspective: cell biology to clinical progress. npj Regenerative Med., 4(22): 1-15.

54. Prins, H. K. and Loos, J. A. (1969): Glutathione: biochemical methods in red cell genetics. N Y D London, 4:126-129.

55. Przadka, P.; Buczak, K.; Frejlich, E.; Gasior, L.; Suliga, K. and Kiełbowicz, Z.(2021):The role of mesenchymal stem cells (MSCs) in veterinary medicine and their use in musculoskeletal disorders; Biomolecules, 11(8): 1141.

56. Qamar, A. Y.; Hussain, T.; Rafique, M. K.; Bang, S.; Tanga, B. M.; Seong, G.; Fang, X.; Saadeldin, I. M. and Cho, J.(2021): The role of stem cells and their derived extracellular vesicles in restoring female and male fertility. Cells, 10(9): 2460.

57. Rajput, V. D.; Singh, R. K.; Verma, K. K.; Sharma, L.; Quiroz-Figueroa, F. R.; Meena, M.; Gour, V. S.; Minkina, T.; Sushkova, S. and Mandzhieva, S. (2021): Recent developments in enzymatic antioxidant defence mechanism in plants with special reference to abiotic stress. Biology, 10(4): 267.

58. Sack, M. N.; Fyhrquist, F. Y.; Saijonmaa, O. J.; Fuster, V. and Kovacic, J. C. (2017): Basic biology of oxidative stress and the cardiovascular system. Journal of the American College of Cardiology, 70(2):196-211.

59. Sagaradze, G. D.; Basalova, N. A.; Efimenko, A. Y. and Tkachuk, V. A. (2020):Mesenchymal stromal cells as critical contributors to tissue regeneration. Frontiers in Cell and Developmental Biology, 8: 917.

60. Sambrook, J.; Fritsch, E. F. and Maniatis, T. (1998): Molecular cloning: a laboratory manual, 2nd Ed.. Cold Spring Harbor Laboratory Press, New York.

61. Sarhan, H. K. A. and Naoum, L. N. (2020): Protective role of royal jelly against gamma radiation induced oxidative stress, cardio-toxicity and organ dysfunctions in male rats. The Egyptian Journal of Hospital Medicine, 78 (1): 62-67.

62. Si, Z. and Wang, X. (2021): Stem cell therapies in alzheimer's disease: applications for disease modeling. Journal of Pharmacology and Experimental Therapeutics, 377(2):207-217.

63. Smith, T. A.; Kirkpatrick, D. R.; Smith, S.; Smith, T. K.; Pearson, T.; Kailasam, A.; Herrmann, K. Z.; Schubertv, J. and Agrawal, D. K. (2017):Radioprotective agents to prevent cellular damage due to ionizing radiation. Journal of Translational Medicine, 15(232): 1-18.

64. Snedecor, C.W. and Cochran, W.C. (1980): Statistical Methods. 7th (Ed.)lowaStae University Press Ames, lowa.

65. Sun, L.; Inaba, Y.; Sato, K.; Hirayama, A.;Tsuboi, K.; Okazaki, R. Chida, K. and Moritake, T. (2018): Dose-dependent decrease in antioxidant capacity of whole blood after irradiation: A novel potential marker for biodosimetry. Scientific Reports, 8(1): 1-8.

66. Tanaka, Y. and Furuta, M. (2021): Biological effects of low-dose $y$-ray irradiation on chromosomes and DNA of Drosophila melanogaster. Journal of Radiation Research, 62(1):1-11.

67. Vahabzadeh, M.; Amiri, N. and Karimi, G. (2018): Effects of silymarin on metabolic syndrome: a review. Journal of the Science of Food and Agriculture, 98(13): 4816-4823.

68. Vargas-Mendoza, N.; Madrigal-Santillán, E.; Morales-González, A.; Esquivel-Soto, J.; Esquivel-Chirino, C.; García-Luna, M.; González-Rubio, Y and Gayosso-de-Lucio, J. A. (2014): Hepatoprotective effect of silymarin. World journal of hepatology, 6(3): 144-149.

69. Vaz, I. M.; Borgonovo, T.; Kasai-Brunswick, T. H.; Santos, D. S. D.; Mesquita, F. C. P.; Vasques, J. F.; Gubert, F.; Rebelatto, C. L. K.; Senegaglia, A. C. and Brofman, P. R. S. (2021): Chromosomal aberrations after induced pluripotent stem cells reprogramming. Genetics and Molecular Biology, 44.

70. Wang, H.; Segaran, R. C.; Chan, L. Y.; Aladresi, A. A. M.; Chinnathambi, A.; Alharbi, S. A.; Sethi, G. and Tang, F. R. (2019): Gamma radiation-induced disruption of cellular junctions in HUVECs is mediated through affecting MAPK/NF-KB inflammatory pathways. Oxidative Medicine and Cellular Longevity, 1-13

71. Wang, Y.; Branicky, R.; Noë, A. and Hekimi, S. (2018): Superoxide dismutases: Dual roles in controlling ROS damage and regulating ROS signaling. Journal of Cell Biology, 217(6):1915-1928. 
72. Williams, J. G. K.; Kubelik, A. R.; Livak, K. J.; Rafalski, J. A. and Tingey, S. V. (1990): DNA polymorphisms amplified by arbitrary primers are useful as genetic markers. Nucleic AcidsResearch, 18(22): 6531-6535.

73. Xiong, Y.; Xiao, C.; Li, Z. and Yang, X. (2021): Engineering nanomedicine for glutathione depletion-augmented cancer therapy. Chemical Society Reviews, 50: 6013-6041.

74. Yan, W.; Diao, S. and Fan, Z. (2021): The role and mechanism of mitochondrial functions and energy metabolism in the function regulation of the mesenchymal stem cells. Stem Cell Research and Therapy, 12(140): 1-17.

75. Yang, H.; Nasab, D. M. and Athari, S. S. (2021): Effects of silymarin and baicalein on glycogen storage in the hepatocytes of rat models of hepatic injury. Hepatitis Monthly, 21(3):e113114.

76. Yao, P.; Zhou, L.; Zhu, L.; Zhou, B.; and Yu, Q. (2020):Mesenchymal stem cells: a potential therapeutic strategy for neurodegenerative diseases. EurNeurol, 83(3): 235-241.

77. Zakaria, K. M. (2017): Effect of gamma ray on reactive oxygen species at experimental animals. OMICS J Radiol., 6(283): 1-5.

78. Zakrzewski, W.; Dobrzyński, M.; Szymonowicz, M. and Rybak, Z. (2019): Stem cells: past, present, and future. Stem Cell Research \& Therapy, 10(68).

79. Zhankina, R.; Baghban, N.; Askarov, M.; Saipiyeva, D.; Ibragimov, A.; Kadirova, B.; Khoradmehr, A.; Nabipour, I.; Shirazi, R.; Zhanbyrbekuly, U. and Tamadon, A. (2021):Mesenchymal stromal/stem cells and their exosomes for restoration of spermatogenesis in non-obstructive azoospermia: a systemic review. Stem Cell Research \& Therapy 12(229): 2-12.

80. Zhou, J; Zhang, Y.; Li, S.; Zhou, Q.; Lu, Y.; Shi, J.; Liu J.; Wu Q. and Zhou, S. (2020):DendrobiumnobileLindl. alkaloidsmediated protection against CCl4-induced liver mitochondrial oxidative damage is dependent on the activation of Nrf2 signaling pathway. Biomedicine and Pharmacotherapy, 129: 110351.

\section{Figures}



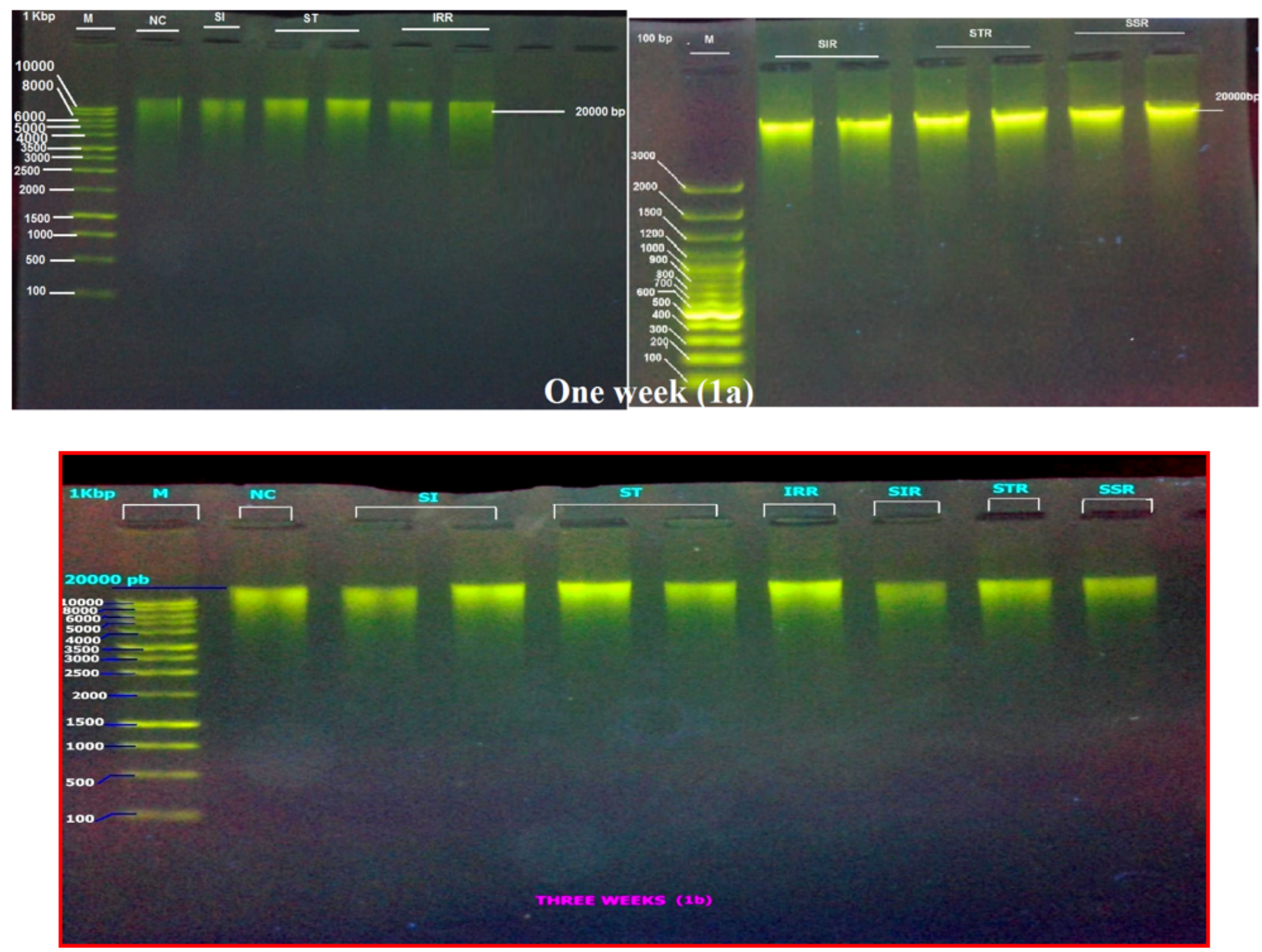

Figure 1

a: Agarose gel electrophoresis of genomic DNA of liver tissue in different groups after one week. Lane 1 is control (NC), lanes 2 is silymarin (SI), lanes 3, 4 are stem cells (ST), lanes 5, 6 are irradiated (IRR), lanes 7, 8 are irradiated with silymarin ( SIR), lanes 9, 10 are irradiated with stem cells (STR) and lanes 11, 12 are silymarin plus stem cell in irradiated groups( SSR) respectively. Lane M (right) is 100 bp ladder "100-3000 bp" DNA marker, while lane M (left) is $1 \mathrm{~K}$ bp ladder "100- 10000 bp" DNA marker.

b: Agarose gel electrophoresis of genomic DNA of liver tissue in different groups after three week. Lane 1 is control (NC), lanes 2,3 are silymarin (SI), lanes 4, 5 are stem cells (ST), lane 6 is irradiated (IRR), lane 7 is irradiated with silymarin ( SIR), lane 8 is irradiated with stem cells (STR) and lane 9 is silymarin plus stem cell in irradiated groups (SSR) respectively. Lane $\mathrm{M}$ is $1 \mathrm{~K}$ bp ladder "100- 10000 bp" DNA marker. 

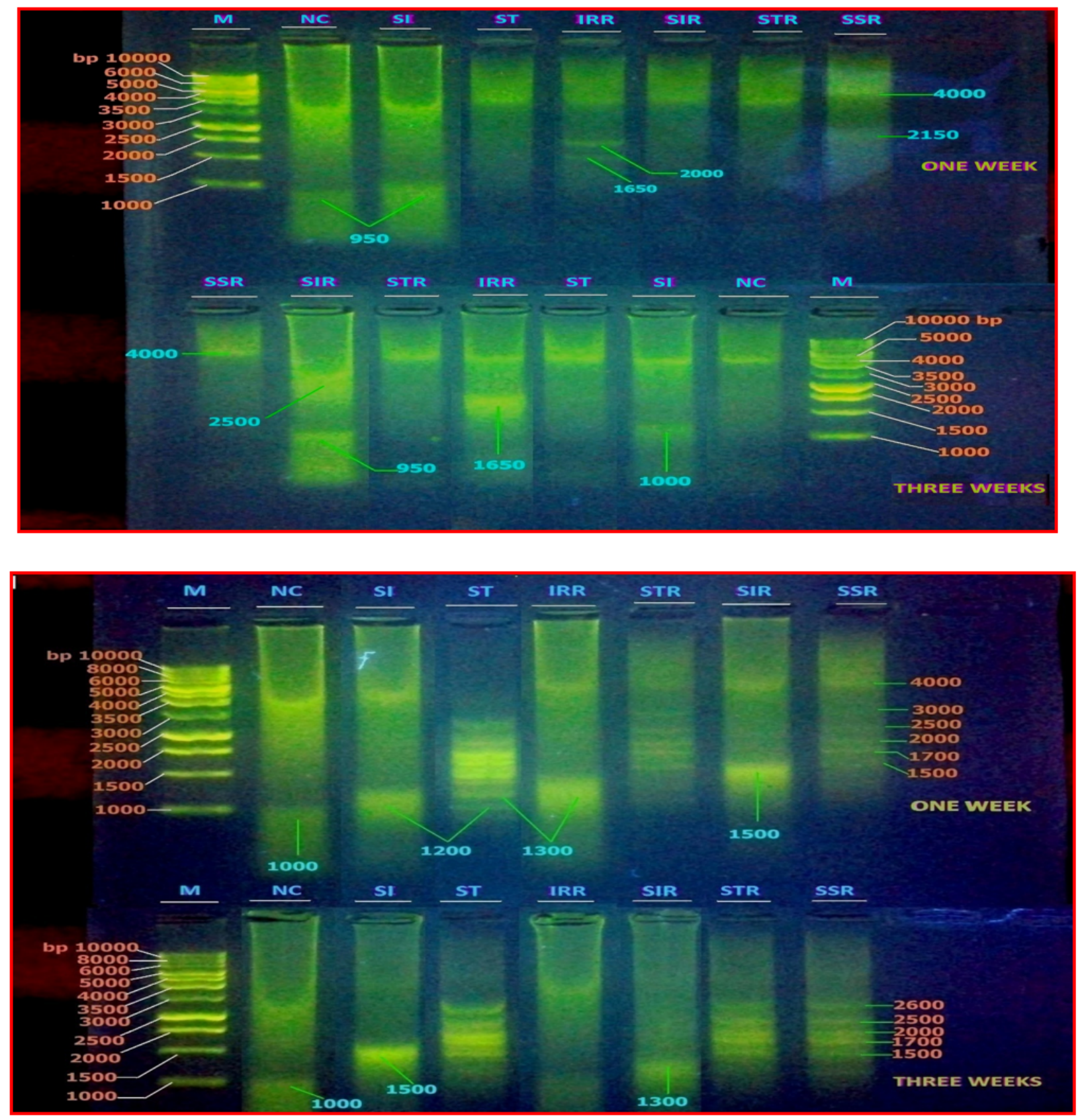

\section{Figure 2}

a: Agarose gel electrophoresis of RAPD-PCR product for primer (Op B-10) from liver tissue in different treated groups after one and three weeks. Control group (NC), silymarin (SI), stem cells (ST), irradiated (IRR), irradiated with silymarin ( SIR), irradiated with stem cells (STR) and silymarin plus stem cell in irradiated groups (SSR) respectively.. Lane M is $1 \mathrm{~kb}$ ladder "100- 10000 bp" DNA marker.

b: Agarose gel electrophoresis of RAPD-PCR product for primer (Op B-14) from liver tissue in different treated groups after one and three weeks. Control group (NC), silymarin (SI), stem cells (ST), irradiated (IRR), irradiated with silymarin ( SIR), irradiated with stem cells (STR) and silymarin plus stem cell in irradiated groups (SSR) respectively.. Lane M is $1 \mathrm{~kb}$ ladder "100- 10000 bp" DNA marker.

\section{Supplementary Files}


This is a list of supplementary files associated with this preprint. Click to download.

- ashrafzSupplementaryInformationfile.pdf 